\title{
Experiment On Abaca Fiber And Its Implementation In Product Making
}

\author{
Hafeezur Rahmaan Mohd Yassin \\ Universiti Sains Malaysia \\ hafeezur@usm.my
}

\author{
Normaziana Hassan \\ Management and Science University \\ normaziana_hassan \\ @ msu.edu.my
}

\author{
Hon Su Sean \\ Universiti Sains Malaysia \\ susean.hon@gmail.com
}

\begin{abstract}
Abaca falls under the same family with a banana plant called Musaceae. In Philippine, abaca fiber is widely used as raw material for fabric and footwear. Meanwhile, abaca plant mainly found in Sabah, Malaysia and it grows without awareness of people. Due to this situation, a research taken by exploring and developing the possibility of the abaca fiber into something that useful and benefits. By using handmade papermaking method and product design approach, the abaca fiber will then be processed into paper and its texture and translucency will be analyzed. After that, a selected paper will be developed into a lampshade and a prototype will be made as the final product and named as II. The characteristic of II is inspired from the Senbon Torii in Fushimi Inari Taisha, Kyoto, Japan. It is a floor and table lamp with structure or body made from wooden. The effect of the lampshade is to create a relaxing and romantic ambiance in a room. The outcome of this research proving that abaca fiber has potential in contributing economic development for local people in Sabah, Malaysia.
\end{abstract}

Keywords: Abaca fiber, papermaking, translucency, product design, economic.

\section{INTRODUCTION}

Abaca plant is close relative to the banana plant. (Schlegel, 2010) They are under the same family,

Musaceae. The botanical name of abaca is Musa Textilis. (FAO, 2018) Abaca plant is originated in the Philippines and have spread to Malaysia and Indonesia. (Brink M, 2003) In Philippine abaca fiber is commonly and widely been used as raw material for fabric, footwear, cordage and craft industries. (FAO, 2018) In Malaysia, abaca plants mainly found in Sabah. (Jacobsen S.D, 2016) Abaca plants are less familiar to the community because it does not produce edible fruit. Therefore, it grows without awareness of people. However, referring to the existing products that produced in Philippine, it also have the same potential to developed the abaca fiber into a product and will create another business opportunity to the local people in Sabah, Malaysia.

There are research about processing banana plant into other uses besides than just harvesting its fruit.

In the research, banana fiber being processed into paper by using papermaking process. (Utusan Melayu, 2008) The banana papers later implied on craft and product making such as paper bag, lamp fixture, greeting card and gift box. (mStar, 2009)

Since abaca plants are under same family with banana, which is Musaceae family, therefore the abaca fiber will then be experiments to make it paper and later will implement it on a product. The core purpose of this research is to explore abaca fiber into a new form of material and turned it into a significant product.

\section{OBJECTIVES}

To identify the existing of abaca fiber's product produced in the market. The purpose is to identify the potential area of new product to be developed.

To experiment and analyze the abaca fiber. The Abaca fiber will be experimented by using handmade papermaking method and make it into certain thicknesses of papers to get the texture and translucency of paper and the results later will then be analyzed.

To propose and prototype. By using product design approach, design will be proposed and develop to suit with the outcome of the experiment. By implementing the selected experimented result of abaca fiber, the prototype will be the new form and area of .product as compared to the existing abaca fiber based products.

\section{METHODOLOGY}

This is a qualitative based research. The literature reviews used to support the issues that being highlighted. Subsequently, experiments on abaca fibers will be carried out. On the experiments, handmade papermaking method will be used. Besides experimenting to make the abaca fibers into paper, their translucency features will also be analyzed. While the experiments are conducted, a design will be proposed by using product design approach and in the end; the design proposed will be prototyped as the final result for the study.

\section{FINDINGS}

Through the literature review, found out that existing products that produced based on abaca fiber are mainly made from the raw fiber by using weaving, twinning and braiding methods while most products from banana fiber are made into a paper which later being developed into few products. Therefore, an experiment on the abaca fibers carried out by using the handmade papermaking method.

According to the news in mStar, 2009, found that lamp fixtures made by banana fiber paper have high commercial value than other products. Additional, the translucency and fibrous effect from the banana paper lamp shows the aesthetic aspect of this product. This is one of the factors that influenced the study being conducted, which by choosing lampshade as a medium to develop the abaca fiber into a product. 
Since the researcher is a product designer, the final outcome of the research will be designing a product. Lighting fixture was chosen as the medium for experiment and will focus on the lampshade effect.

\section{Experiment on Abaca Fiber}

Following is the experiment had been conducted to complete the research:

i) Experimenting abaca fiber through handmade papermaking process Procedure:

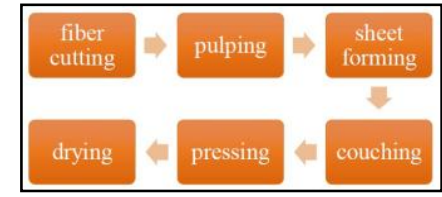

Figure 1: Abaca fiber handmade papermaking process

Result:

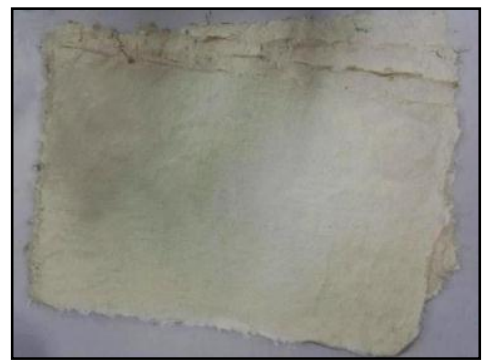

Figure 2: Result of abaca fiber - handmade paper

The experiment succeeded in demonstrating that abaca fibers can be processed into paper by using handmade papermaking method.

ii) Producing different thicknesses of abaca fiber sheet (press and without press) Procedure:

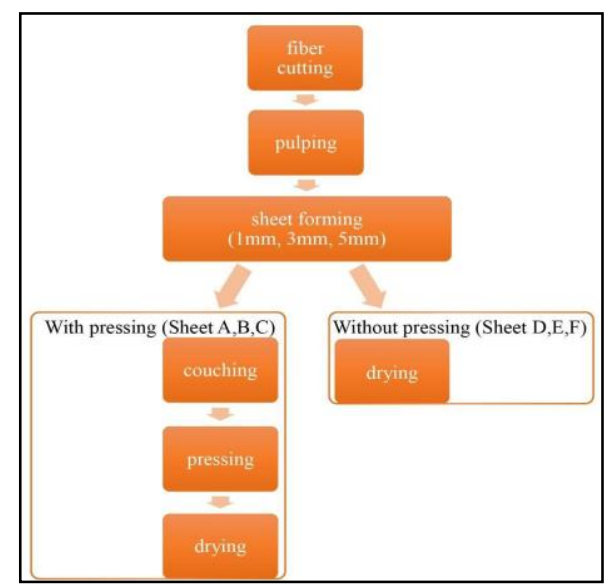

Figure 3: Process of making paper with different thicknesses (press and without press)

The thicknesses of papers were measure by using digital caliper after drying.
Result:

Table 1: Thicknesses Of Abaca Fiber Sheet (With Pressing)

\begin{tabular}{|c|c|c|}
\hline \multirow{2}{*}{ Sheet } & $\begin{array}{c}\text { Thickness before } \\
\text { drying }(\mathrm{mm})\end{array}$ & $\begin{array}{c}\text { Thickness } \\
\text { after drying } \\
(\mathrm{mm})\end{array}$ \\
\hline A & 1 & 0.29 \\
\hline B & 3 & 0.45 \\
\hline C & 5 & 0.76 \\
\hline
\end{tabular}

Table 2: Thicknesses Of Abaca Fiber Sheet (With Pressing)

\begin{tabular}{|c|c|c|}
\hline $\begin{array}{c}\text { Shee } \\
\mathrm{t}\end{array}$ & $\begin{array}{c}\text { Thickness } \\
\text { before drying } \\
(\mathrm{mm})\end{array}$ & $\begin{array}{c}\text { Thickness } \\
\text { after drying } \\
(\mathrm{mm})\end{array}$ \\
\hline D & 1 & 0.46 \\
\hline E & 3 & 0.75 \\
\hline F & 5 & 1.32 \\
\hline
\end{tabular}

iii) Experiment on the translucency of abaca fiber sheets (different thicknesses) with various type of bulb. Procedure:

Sheets A, B, C, D, E, F were test with warm white bulbs (4-watt, 5-watt and 8-watt) and cool daylight bulbs (5-watt and 8-watt).

Result:

Table 3: Result of sheets tested with warm white bulbs

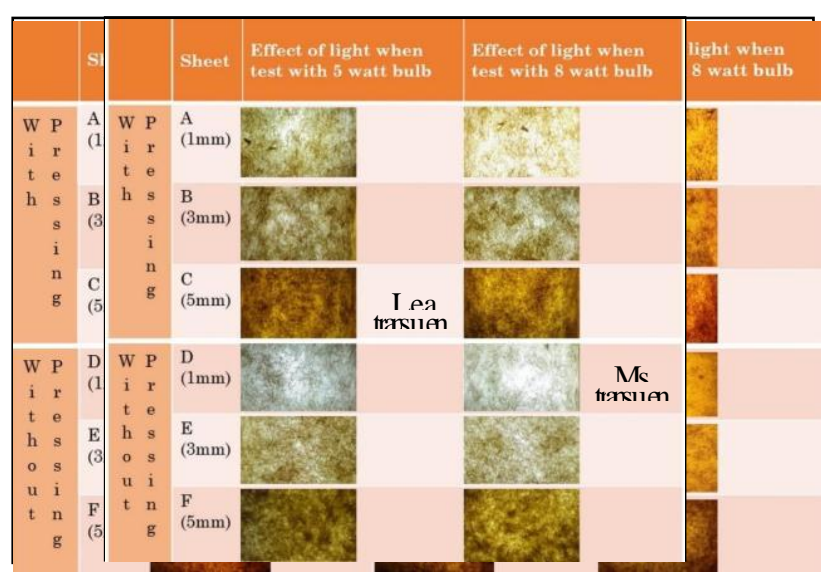

Table 4: Result of sheets tested with cool daylight bulbs

\section{DISCUSSION ON THE EXPERIMENTS}

Based on the experiments done, due to the thickness, toughness, ability to shape and translucency of sheet E (3mm, without pressing) has been selected as a material for the lampshade design. The 4watt LED warm white bulbs selected as to match with the proposed design. 


\section{Design Concept}

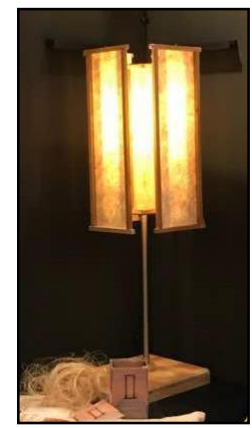

Figure 4: Final Prototype

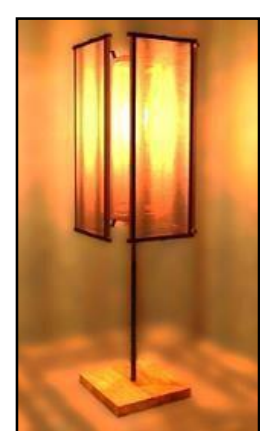

Figure 4: 3D rendering

The design concept of II is inspired from the Senbon Torii in Fushimi Inari Taisha, Kyoto, Japan. The character repetition of vermillion torii gate which run into thousand and resulting maze. The structure of torii gate is more to simplicity which only consist of two post and 2 crossbars. When simplicity match with repetition the resulting outcome is interesting. Repetition of simple structure become the aesthetic point of the lampshade. II is a Japanese style floor and table lamp which its lampshade is made from abaca fiber. It creates a relaxing and romantic ambience in the room. Besides, also creating a conducive atmosphere for sleeping or rejuvenation and let users feel comfortable and give a sense of bliss.

The material used for making II are mostly natural material. The materials used include abaca fiber paper, pinewood and rubber wood. All these materials are remained in their natural color to represent the beauty of nature.

There are many aspects need to be considered during design development in order to create a significant product. Functional prototype of II floor and table lamp was successfully made under various consideration such as aesthetic, ergonomic, construction method, safeness, sustainability, functionality, costing etc.

\section{CONCLUSION}

The main objectives of the research are to experiment the abaca fiber and imply it in product

design making. The research aimed are to develop another area of potential business for abaca fiber. It can become an economy source especially for the local people in Sabah, Malaysia. This support by; In Malaysia, abaca plants mainly found in Sabah. (Jacobsen S.D, 2016)

There is some recommendation for the further research of abaca fiber. The abaca fiber can be dyed by some natural dye as to make paper with various colors. Paper with different color can provide more choices for various products. The next suggestion is to experiment on combination of abaca fiber with other natural fiber to produce another new product for new potential area of economic development.

\section{REFERENCES}

Brink M, Escobin RP, editors. (2003). Plant Resources of South-East Asia No. 17: Fiber Plants. Leiden, Netherlands: Backhuys Publishers.

Food and Agriculture Organization of the United Nations. (2018). Abaca. Retrieved from http://www.fao.org/economic/futurefibres/fibres/abaca0/en/

Jacobsen, S.D. (2016, April). SUSTAINABLE FIBRES: WHAT IS ABACA? $\quad$ Retrieved from https://www.trustedclothes.com/blog/2016/04/27/sustainablefibres-what-is- abaca/\#_edn10 mStar. (2009, June 25). Hasilkan kertas daripada serat batang pisang. Retrieved from http://www.mstar.com.my/lain-lain/rencana/2009/06/25/hasilkankertas-daripada-serat-batangpisang/

Schlegel, R. H. (2010). Dictionary of Plant Breeding. Retrieved from http://doi.org/10.1002/1521 - 3773(20010316)40:6<9823::AIDANIE9823>3.3.CO;2-C Utusan Melayu. (2007, February 21). Penyelidik USM Berjaya cipta kertas dari serat batangpisang.

Retrieved from http://ww1.utusan.com.my/utusan/info.asp?y=2007\&dt=0221\&pu b=Utusan_Malaysi \&sec=Terkini\&pg=bt_01.htm

Brink M, Escobin RP, editors. (2003). Plant Resources of South-East Asia No. 17: Fiber Plants. Leiden, Netherlands: Backhuys Publishers.

Food and Agriculture Organization of the United Nations. (2018). Abaca. Retrieved from http://www.fao.org/economic/futurefibres/fibres/abaca0/en/

Jacobsen, S.D. (2016, April). SUSTAINABLE FIBRES: WHAT IS ABACA? mStar. (2009, June 25). Hasilkan kertas daripada serat batang pisang.

Schlegel, R. H. (2010). Dictionary of Plant Breeding. Utusan Melayu. (2007, February 21). Penyelidik USM Berjaya cipta kertas dari serat batang pisang. 